\title{
Structural reforms in payment systems to avoid another systemic crisis
}

\author{
Sergio Rossi \\ Department of Economics, University of Fribourg, Switzerland
}

This paper shows how a defective architecture for domestic and international payments has made it possible for banks to exploit the endogenous nature of money in a variety of purely speculative financial-market transactions that have led to the eruption of a global systemic crisis. I elaborate on a monetary-structural reform, which should make sure that no bank will any longer be in a position to blur the distinction between money and credit, as this confusion in the banks' books originates various asset bubbles as well as systemically important financial institutions, both of which are major contributors to making the system increasingly fragile as time goes by. This reform of domestic payment systems will not be enough to avoid so-called global imbalances at an international level. I therefore propose, in the spirit of Keynes, a structural reform of the international monetary system, arguing for the emission of a supranational money in settlement of every individual transaction between any two monetary spaces.

Keywords: bank money, financial crises, payment systems

JEL codes: $E 42, E 51, F 33$

\section{INTRODUCTION}

The systemic crisis that has been devastating a number of Western economies since the demise of Lehman Brothers in the United States, on 15 September 2008, is the result of structural failures in payment systems at national and international levels. (Re)regulation of a variety of banks' and their managers' forms of behaviour (as proposed and in part already carried out by domestic regulators and by the Basel Committee on Banking Supervision) is therefore not enough to prevent another systemic crisis from occurring. The structural origins of the current crisis require a structural reform of both national and international payment systems. In this paper I will therefore point out and address the monetary-structural factors of this crisis, which is the first systemic crisis of finance-led economic systems. I begin by explaining in Section 2 how a defective structure of domestic and international payments has made it possible for banks and nonbank financial institutions, particularly in the United States, to exploit the endogenous nature of money for their own short-term profit in a variety of purely speculative financial-market transactions that have led to the eruption of a global systemic crisis. In Section 3, I will elaborate on a monetary-structural reform, which should ensure that no banking institution will any longer be in a position to blur the distinction between money and credit, because this confusion in banks' books can originate various asset bubbles as well as systemically important financial institutions, which are major contributors to making the whole economic system increasingly 
fragile as time goes by. The reform that I propose for domestic payment systems, however, will not be enough to avoid so-called 'global imbalances' at the international level. I will therefore elaborate on this in Section 4, in order to propose, in the spirit of Keynes, a structural reform of the international monetary system. Considering the plan that Keynes presented at the Bretton Woods conference in July 1944, I will argue that a supranational money, to be issued by an international settlement institution in the final payment of every individual transaction between any two monetary spaces, can guarantee that no country will any longer have the 'exorbitant privilege' (Gourinchas and Rey 2007, p. 12) of paying for its net imports with a simple promise of payment denominated in a so-called 'key currency', whose 'duplicates' (Rueff 1963, pp. 323-324) are considered as objects of trade and speculation, thereby impairing the working of the global economy. In the conclusion (Section 5), I will summarize my main arguments and briefly comment upon the euro-area crisis that is still unresolved at the time of writing.

\section{MONEY AND PAYMENTS WITHIN AND ACROSS MONETARY SPACES}

A monetary space is defined by the extent of the payment and settlement system run by a central bank in its functions as money and credit provider to participating banks as well as to nonbank financial institutions (Rossi 2007, pp. 69-79). The essential starting point that one has to consider therefore concerns money and, notably, its nature and mechanism of emission in any given payment. As Schmitt (1996, p. 88) observes, indeed, '[m]oney and payments are one and the same thing', because money is issued within payments in order for them to be finally carried out. The finality of payments is crucial, as it makes sure that the 'seller of a good, or service, or another asset, receives something of equal value from the purchaser, which leaves the seller with no further claim on the buyer' (Goodhart 1989, p. 26). This raises immediately the question about the nature of money, to explain why the latter has the capacity to deliver payment finality when any bank issues a number of money units in order for the payer to settle his debt to the payee.

To address this question, the so-called 'monetary circuit theory' provides the right conceptual framework, in the sense that it focuses on the emission of money as banks issue it in payments on any kinds of markets. As Graziani (1990) points out, money 'only comes into existence the moment a payment is made. At that moment, in one and the same act, money is created, the borrower becomes a debtor to the bank and the agent receiving a payment becomes the creditor of the same bank' (p. 11, emphasis in the original). Although this view blurs the distinction between money and credit (as the payer does not borrow from the bank necessarily), it correctly highlights that the bank is merely a go-between in the payment that involves the buyer and the seller of any given items (Figure 1).

Obviously, the bank issuing the means of final payment between the payer and the payee in Figure 1 is neither buying nor selling anything, as it is just providing to the agents the number $(x)$ of money units (m.u.) that they need to carry out the relevant payment. This is enough to understand that money is not a stock but a flow. More precisely, it is the action through which a payer discharges his debt obligation against the payee, as a result of which the latter has a purchasing power in the form of a bank deposit (Table 1).

Table 1 shows that, as a result of the payment (which is a flow), there is a stock of purchasing power recorded by a bank in the name of the payee. Starting from tabula rasa, to avoid explaining the formation of a bank deposit by a transfer of a pre-existing 


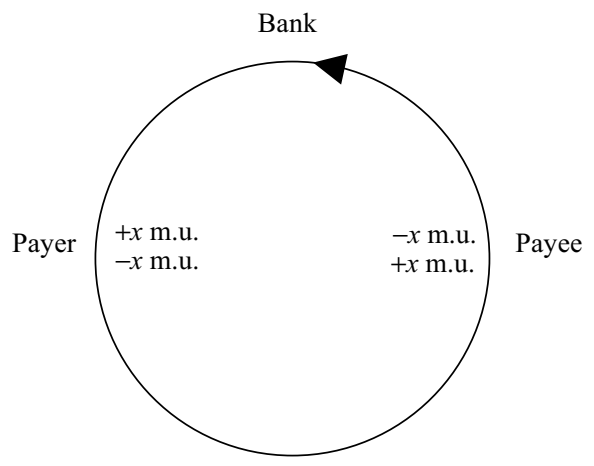

Figure 1 The emission of money as a flow between the payer and the payee

Table 1 The bank loan and deposit resulting from a payment

\begin{tabular}{lll}
\hline & \multicolumn{2}{c}{ Bank } \\
\hline Assets & Liabilities \\
\hline Loan to the payer & $+x$ m.u. & Deposit of the payee \\
\hline
\end{tabular}

deposit - as this would leave the origin of the latter unexplained - one clearly notices that payments give rise to debt-credit relationships with respect to the banking system (represented by a single bank here). This can explain why Innes (1913, p. 403) argued that " $[t]$ here is thus a constant circulation of debts and credits through the medium of the banker who brings them together and clears them as the debts fall due. This is the whole science of banking as it was three thousand years before Christ, and as it is to-day'. Indeed, the nature of money has not changed from the historical period when its functions were carried out using wooden tallies, precious metals or any other material, to the current period of purely book-entry numbers in banks' ledgers (see Rochon and Rossi 2015 for analytical elaboration on this point).

As the banks' double-entry book-keeping shows (see Table 1), money is an 'assetliability' (Schmitt 1975, p. 13), because it measures the entries recorded on both the assets and liabilities sides of the bank's ledger when the latter carries out the relevant payment. As such, money allows the payment to occur, measuring both the payer's debt and the payee's credit, which the bank records as a memory item. There is thus an essential distinction to be considered, in theory as well as practice, between money and bank deposits: money carries out payments, whilst bank deposits finance them owing to their purchasing power (to be explained rather than assumed). This means that money has no purchasing power, unless it is associated with production when the latter occurs (see Bossone 2001, p. 870). If so, then the payment of firms' production costs gives rise to bank deposits that 'integrate' money and output as a (numerical) form and its (physical) content. As Cencini (1995, p. 16) explains, in that payment 'money takes the place of the physical product and becomes its numerical form, so that the exchange between money and output defines their integration: money and output become the two complementary faces of a unique object' (national income).

In this regard, money and credit are linked by the fact that firms obtain a credit line from a bank in order for them to pay out wages (this is the so-called 'initial finance' in 
the monetary theory of production; see for instance Graziani 2003). In spite of this, however, it would be wrong to argue - or to infer from the mechanism of money emission - that banks create money and endow it with a positive purchasing power starting from scratch. Despite numerous monetary-circuit authors referring to 'credit money' in their writings, all that banks can do (and do indeed) is to enter a number (of money units) in their assets and liabilities whenever they issue the means of final payment between any two agents. In fact, the credit underlying this payment does not come from the bank but, eventually, from the payee: ' $[\mathrm{t}] \mathrm{he}$ supply of credit is the supply of a positive amount of income and requires the existence of a bank deposit (a stock), whereas the supply of money refers to the capacity of banks to convey payments (flows) on behalf of their clients' (Cencini 2001, p. 7). According to the view that bank loans create deposits, this means that by drawing on the credit line granted by the bank, the payment of a firm's production costs gives rise to a deposit, which is saved by wage earners and whose amount is therefore instantaneously lent by the bank to finance that very firm's expenditure on the labour market. 'Through the financial intermediation of banks, savings are instantaneously lent by their initial owners and spent by their borrowers' (Cencini 1995, p. 71), although neither bank depositors nor bank borrowers are necessarily aware of this intermediation (see Gnos 1998). Table 1 substantiates this argument in book-keeping terms, and confirms also Moore's (2003, p. 245) understanding that 'saving is the accounting record of investment'.

The monetary-structural flaw originating the systemic crisis after the bankruptcy of Lehman Brothers on 15 September 2008 resides in these mechanisms. As a matter of fact, the credit lines granted by any banks can be used in different ways: they can be drawn upon either in order for firms to dispose of 'initial finance' productively (spending the relevant amount in an income-producing transaction) or in order for any borrowers to obtain various goods, services or assets through separate income-consuming expenditures. The results of income-producing expenditures financed by bank loans are sound, as far as the firms' debts are associated to the newly produced income available in the form of bank deposits within the whole economic system. In this case the thus generated amounts of debt and income are identically equivalent, so that no discrepancy arises that could eventually impede the reimbursement of the relevant bank loans across the whole economy. By contrast, when the credit lines are used to carry out income-consuming expenditures, they give rise to a debt for the relevant borrowers, to which no newly produced income corresponds. This is problematic when that debt has to be paid back, as there is no available income for this to occur, unless a new credit line is granted to allow for a new income to be formed and to be spent in order to reimburse the initial loan. In this case, however, there will always be an excessive debt, as the total sum of available income is not enough to reimburse all outstanding debt. As far as banks are willing to grant further credit lines to their borrowers, as this occurs (generally speaking) when an asset bubble is inflating, the macroeconomic debt-income discrepancy remains hidden and does not pose a threat, apparently, to the financial stability of the whole economic system - as maintained, for instance, by Greenspan (2004) when the real-estate bubble was inflating in the United States during the 1996-2006 period (see Stellian 2010). Things change abruptly and dramatically when banks are unwilling to roll over maturing debts, thereby reducing the amount of new credit lines they open to any borrowers. In that case, as the 2008-2009 global financial crisis has shown, a number of systemic effects materialize, within the banking system as well as in the economy as a whole. This is so because banks are special, as pointed out above: they provide both money and credit through a structure of 
double-entry book-keeping that does not (yet) allow banks to distinguish between these two essentially separate but functionally related activities in their books.

This monetary-structural problem, which has to do with banks' accounting and not merely with bankers' forms of behaviour, plays also a crucial role in the occurrence of so-called 'global imbalances' in foreign trade. Whenever a 'key-currency' country, say the United States, imports more goods and services than it is able to export, it 'pays' its trade deficit without making any sacrifice (either in terms of an income that it surrenders to the rest of the world, or in terms of goods, services and/or assets that it delivers to its trading partners): the deposits denominated in US dollars that any US importer spends in his final payment of the exporter residing in the rest of the world (say, in China) remain within the US banking system, as a result of the double entries necessarily recorded in the banking system of the importing country (Table 2).

As a result of the loans-make-deposits causal chain, Table 2 shows that country A (a net importing country in this stylized case) owes a deposit measured by $x$ units of money A to country $\mathrm{C}$, whose banking system records just the 'image' of this deposit in its official reserves, crediting the payee (the local exporter) with an equivalent amount (of $y$ units) of money C. Even though a final payment occurs between the importer in country A and the exporter in country $\mathrm{C}$, this is not enough to make sure that payment finality applies also between the two countries that are involved by foreign trade. In fact, as Table 2 illustrates, country A does not finally pay but remains indebted to country $\mathrm{C}$ : the latter country still has a claim (in the form of a deposit) on the former country. The relevant deposit, indeed, does not leave the banking system of the paying country (A), whose trade deficit (worth $x$ MA) is therefore 'without tears' (Rueff 1963, p. 322). More precisely, the net importing country records a 'payment deficit' (Machlup 1963, p. 256), as it does not really pay for its trade deficit. This is so because, in contrast to its nature as means of payment, money A (a 'key currency') is considered as if it were an asset per se; that is to say, an object of trade. In fact, any national currency is a promise of payment when it is used within the international economy (which is a pure exchange economy, as all production takes place within countries and not in the economic space existing between them). It should not come as a surprise, therefore, that the present 'non-system' (Williamson 1977, p. 73) for international payments originates global imbalances, which can then ravage the domestic economies: 'If I had an agreement with my tailor that whatever money I pay him returns to me the very same day as a loan, I would have no objection at all to ordering more suits from him' (Rueff and Hirsch 1965, p. 2).

This international monetary disorder, which originates both global imbalances and erratic exchange-rate fluctuations (see Cencini 2010), also has tremendous effects on the domestic economy of 'key-currency' countries. Let us refer to the case of the US

Table 2 The duplication of bank deposits denominated in 'key currencies'

\begin{tabular}{|c|c|c|c|}
\hline \multicolumn{4}{|c|}{ Banking system of importing country $\mathrm{A}\left(\mathrm{BS}_{\mathrm{A}}\right)$} \\
\hline Assets & & Liabilities & \\
\hline Loan to the payer & $+x \mathrm{MA}$ & Deposit of $\mathrm{BS}_{\mathrm{C}}$ & $+x$ MA \\
\hline \multicolumn{4}{|c|}{ Banking system of exporting country $\mathrm{C}\left(\mathrm{BS}_{\mathrm{C}}\right)$} \\
\hline Assets & & Liabilities & \\
\hline Official reserves $(+x$ MA) & $+y \mathrm{MC}$ & Deposit of the payee & $+y \mathrm{MC}$ \\
\hline
\end{tabular}

Note: $\mathrm{MA}=$ units of money $\mathrm{A} ; \mathrm{MC}=$ units of money $\mathrm{C}$. 
economy, considering notably the so-called 'subprime' crisis that erupted in 2007 and all its negative consequences that have devastated the domestic and global economy. It is a matter of both fact and accounting logic (as explained above) that 'the huge liquidity denominated in US dollars that exists as a result of the enormous US current account deficit cannot be but "recycled" in the local financial sector, providing the means for the creation and then bursting of bubbles that may ravage the local economy' (Rossi 2009, p. 2). As US banks will have to pay interest on all deposits recorded with them, including those deposits that have been formed in the payment of the US trade deficit (see Table 2), they are induced to increase the amount of credit in order to earn interest on it, enabling them to pay interest on their clients' deposits. This is so much so if - as has been occurring increasingly during the 1980s, 1990s and 2000 s - banks can rely on securitization and offloading practices in order for them to dispose of credit risks and earn various fees and commissions in so doing (see Rossi 2010 for analytical elaboration on this point).

All in all, there is enough 'empirical evidence' so far to understand the monetarystructural origin of the current global systemic crisis, in order to design the reforms that are necessary to eradicate the original flaws. Let us elaborate on these reforms by distinguishing the domestic and international levels.

\section{REFORMING THE DOMESTIC STRUCTURE OF BANKS' BOOK-KEEPING}

As Ricardo (1824 [1951], p. 276) pointed out with respect to the central bank in the United Kingdom in his time, money and credit provided by banks could be recorded separately in book-keeping terms 'without the slightest loss of advantage, either to the country, or to the merchants who receive accommodation from such loans'. In fact, separating money from credit in banks' ledgers allows all stakeholders to assess whether or not a given bank is in a position to provide further credit lines without impairing the money-to-output relationship. This purely technical reform in banks' books does not limit but can actually enhance output growth, as it contributes to strengthening the financial stability of the banking system in the countries that adopt it (see Rossi 2011). Along the lines first suggested by Schmitt (1984, pp. 192-209) considering money endogeneity, any bank will have to book all its operations via two distinct but interrelated accounting departments: the monetary (or issue) department of banks will record all emissions of money in payments that give rise to an income that is new within the whole economy. As this occurs on the labour market only, all payments of wages will originally be entered in this (first) department of banks. The second (financial) department will be in charge of entering the result of all those payments that do not concern income-generating transactions. These payments occur on either product or asset markets. On the latter market, income is transferred from the payer to the payee without any change in income at the macroeconomic level, whilst on the former market income is destroyed in macroeconomic terms, in so far as the seller on the market for produced goods and services thereby obtains the 'final finance' that allows him to reimburse his initial bank loan, which was instrumental in order to compensate the relevant wage earners on the labour market.

Let us consider a stylized case, dividing it into three periods corresponding to (i) the compensation of a firm's wage earner, (ii) the sale of a share of this firm's output, and (iii) the loan that a bank grants to some agent in order for the latter to purchase a given asset on the financial market. In the current framework, as explained in the previous 
section, banks may exploit the loan-to-deposit causal chain to increase the volume of deposits, although no new output corresponds to them originally. This is especially the case when banks 'move forward in step' (Keynes 1930 [1971], p. 23): in that case, their lending capacity has no endogenous limit, because no bank will thereby have an interbank debt to settle and therefore will not demand settlement balances at the central bank (see Panzera and Rossi 2011 for analytical elaboration with regard to systemically important financial institutions). In the structurally reformed book-keeping system, this destabilizing factor cannot exist. The three events that correspond to the three periods considered above will be recorded by the banking sector as shown in Table 3.

The payment of wages being an income-generating expenditure, it involves both the monetary and the financial departments of the bank that carries it out (to simplify what can be simplified without any loss of significance in this respect, let us assume that the banking sector is represented by a single bank). In Table 3, entry (1.1) shows that the number of money units to carry out this payment are debited to the payer (firm F) and credited instantaneously to the financial department, as the payee (worker W) obtains a financial claim on produced output in the form of a bank deposit recorded by entry $\left(1.1^{\prime}\right)$. If by the end of the same day, as this is usual practice for the calculation of interest, the firm is not in a position to repay its debt to the bank, then entry (1.2) records the loan that the latter grants to the former, and that has to be paid back later on. This amounts to transforming a monetary debt into a financial debt (the end-of-day balance in the monetary department is nil, as the financial department of the bank has taken over the relevant positions through entries $\left(1.1^{\prime}\right)$ and $\left(1.2^{\prime}\right)$, whose net balance records in this case the loan to firm $\mathrm{F}$ and the deposit of worker $\mathrm{W}$ ).

Table 3 The results of distinct payments across banks' monetary and financial departments

Bank

Monetary department (I)

\begin{tabular}{llll}
\hline Assets & \multicolumn{3}{l}{ Liabilities } \\
\hline$(1.1)$ Credit to firm F & $+x$ m.u. & Financial department (II) & $+x$ m.u. \\
$(1.2)$ Credit to firm F & $-x$ m.u. & Financial department (II) & $-x$ m.u. \\
$(*)$ & 0 & & 0 \\
\hline
\end{tabular}

Bank

Financial department (II)

\begin{tabular}{llll}
\hline Assets & \multicolumn{3}{l}{ Liabilities } \\
\hline$\left(1.1^{\prime}\right)$ Monetary department (I) & $+x$ m.u. & Deposit of worker W & $+x$ m.u. \\
$\left(1.2^{\prime}\right)$ Loan to firm F & $+x$ m.u. & Monetary department (I) & $+x$ m.u. \\
$(2)$ & & Deposit of worker W & $-y$ m.u. \\
& & Deposit of firm F & $+y$ m.u. \\
$(3.1)$ Loan to borrower B & $+(x-y)$ m.u. & Deposit of trader T & $+(x-y)$ m.u. \\
$(3.2)$ & & Deposit of worker W & $-(x-y)$ m.u. \\
& & Deposit of borrower B & $+(x-y)$ m.u. \\
$(*)$ Loan to firm F & $x-y$ m.u. & Deposit of trader T & $x-y$ m.u. \\
\hline
\end{tabular}

Note: $(*)$ is the balance of those entries that are recorded in the relevant department. 
In the second period, when the wage earner (W) disposes of $y$ (out of $x$ ) units in his bank deposit on the market for produced goods and services, the relevant firm (assuming it is the same as above, F) obtains on this market the funds (or 'final finance') that it needs to cover the production costs of sold output (entry 2), and is thereby in a position to reimburse the bank. This reimbursement occurs in order for the firm to reduce the outstanding amount of debt (hence the interest it will have to pay on it) and to confirm its creditworthiness, thus allowing it to obtain new bank loans when it needs 'initial finance' for a new production to begin. At the end of this second period, therefore, the outstanding amount of the firm's debt (which corresponds to the deposit still owned by the worker) is equal to $(x-y)$ money units. This is the amount of income still deposited within the banking sector (a single bank in my stylized case). It is therefore the maximum amount that the banking sector as a whole may consider when any agent asks it for a loan that is not intended to increase available income.

Assume therefore that, in the third period, some agent, B, intends to borrow from a bank in order for this agent to buy various financial assets from a given trader, T. B can be another bank, a nonbank financial institution or any other nonbank agent. The question to focus upon concerns the amount of the loan that B obtains from the relevant bank. As the loans-create-deposits mechanism has no endogenous limit (see above), the bank's double-entry book-keeping has to be structured in order to make sure that this mechanism does not lead eventually to financial instability across the whole economic system. This is the reason why banks' accounting has to be split into two separate departments as explained above. As this occurs, the bank as well as its stakeholders will be in a position to know, at any point in time, the maximum amount of income that is saved and that can be spent across the system for financial market transactions. These transactions, let us repeat, do not generate further income within the whole economy: they should not be carried out according to the principle that loans generate deposits, because in this case the newly formed deposits would be devoid of any original purchasing power (as such, they would be originating inflation, notably on the asset market). It is the principle that deposits make loans that banks and other financial intermediaries must respect, in order for their lending not to disrupt financial stability in the whole system. This is why the amount recorded through entry (3.1) in Table 3 should not be higher than $(x-y)$, as this is the available amount of income in the form of bank deposits. If so, then by the end of the same period original income holders (W) have to dispose of the same amount $(x-y)$ in purchasing those assets that the borrower must sell in order for him to finance his purchase of financial assets from T. Entry (3.2) is therefore the sine qua non condition to respect in order for the banking sector to record entry (3.1) during that period, without generating a discrepancy between money and output which would pose a threat to systemic financial stability. As the end-of-period balance in the financial department clearly shows, the money-to-output relation remains sound after the financial transactions recorded as entries (3.1) and (3.2) in Table 3, as the total amount of outstanding debt (owed by F) is identically equal to available income (owned by $\mathrm{T}$ ) within the whole economic system.

\section{REFORMING THE INTERNATIONAL MONETARY STRUCTURE OF PAYMENTS}

The separation of money and credit activities in banks' book-keeping is a necessary yet insufficient condition to make sure that financial stability prevails across the economy. As regards foreign trade on goods, services or assets, the international economy also 
needs the institution of payment finality between different monetary spaces (see above). This is why a supranational settlement institution has to be set up, in order for it to issue a means of final payment for countries defined as the set of their own residents.

Keynes (1942 [1980], p. 168, emphasis added) already pointed out that '[w]e need an instrument of international currency having general acceptability between nations' As he argued in this respect, 'an instrument of currency used by each nation in its transactions with other nations, operating through whatever national organ, such as a Treasury or a central bank, is most appropriate, private individuals, businesses and banks other than central banks, each continuing to use their own national currency as heretofore' (ibid., p. 168). Indeed, to date, payment finality already occurs for any residents (individuals, businesses, financial institutions and the general government sector), in both their domestic and cross-border transactions. By contrast, as explained above, international payments carried out by disposing of 'key currencies' are not final for the countries involved. This is why there is a need to transform today's international barter economy (where any trade deficits imply also payment deficits for the net importing country) into an international monetary economy. As Keynes (1942 [1980], p. 34) pointed out, elaborating on this principle, '[i]nternationally all transactions [have] to be cleared between central banks, operating on their accounts with an International Clearing Bank'. Referring to modern payment systems, notably those that are used for the settlement of securities transactions within and across a country's borders, this means that the international payment system to be set up should adopt the real-time gross-settlement (RTGS) protocol, in order for every payment order to be processed as soon as it is entered into the system, provided that the payer country disposes of enough settlement balances at the international settlement institution. In the contrary case, the payer country will have either to increase exports or to sell its assets, up to the amount required to settle its debt to the rest of the world. Be that as it may, this protocol will make sure that '[any] trading transaction must necessarily find its counterpart in another trading transaction sooner or later' (ibid., p. 18). This will 'generalise the essential principle of banking, as it is exhibited within any closed system, through the establishment of an International Clearing Bank. This principle is the necessary equality of credits and debits, of assets and liabilities' (ibid., p. 44).

Let us elaborate on this principle with a stylized example that refers to the fictitious case illustrated in Table 2. Suppose that trade between China and the United States is finally paid through an international settlement institution that uses an RTGS protocol, as explained above. The US importer must dispose of US dollars ( $x \mathrm{MA})$ in the final payment of the Chinese exporter, who obtains the property right on a deposit of yuan ( $y$ MC). This reproduces the current practice at the residents' level (see Table 2). It is also in line with the principle already stated by Schumacher (1943, p. 150) as regards international payments via the supranational settlement institution to be set up in order to guarantee payment finality at international level. In particular, entry (1) in Table 4 shows that the importer in country A is debited of $x$ MA, whilst entry $\left(1^{\prime \prime}\right)$ testifies that the exporter in China obtains (the property right on) a deposit of $y \mathrm{MC}$ in the national banking system.

As a go-between, the international settlement institution records the debt of country A and the credit of country $\mathrm{C}$ in its own ledger, as shown by entry $\left(1^{\prime}\right)$. This monetary role does not imply that the international settlement institution provides credit to the importing country (A). Indeed, to make sure that the debtor country surrenders a purchasing power when its residents settle their foreign debt, the payment carried out by the international settlement institution between countries $\mathrm{A}$ and $\mathrm{C}$ has to be instantaneously coupled with a reciprocal payment, from country $\mathrm{C}$ to country $\mathrm{A}$, which has 
Table 4 The delivery-versus-payment protocol applied to international transactions

\begin{tabular}{|c|c|c|c|}
\hline \multicolumn{4}{|c|}{ Banking system of importing country $\mathrm{A}\left(\mathrm{BS}_{\mathrm{A}}\right)$} \\
\hline Assets & & Liabilities & \\
\hline $\begin{array}{l}\text { (1) Loan to the payer } \\
\text { (2) Securities (sold to country C) } \\
\text { Deposit with ISI }\end{array}$ & $\begin{array}{l}+x \text { MA } \\
-x \text { MA } \\
+x \text { MA }\end{array}$ & Deposit of ISI & $+x$ MA \\
\hline (*) Loan to the payer & $x$ MA & Securities & $x$ MA \\
\hline \multicolumn{4}{|c|}{ International Settlement Institution (ISI) } \\
\hline Assets & & Liabilities & \\
\hline $\begin{array}{l}\left(1^{\prime}\right) \text { Loan to country A } \\
\left(2^{\prime}\right)\end{array}$ & $+z$ bancor & $\begin{array}{l}\text { Deposit of country C } \\
\text { Deposit of country C } \\
\text { Deposit of country A }\end{array}$ & $\begin{array}{l}+z \text { bancor } \\
-z \text { bancor } \\
+z \text { bancor }\end{array}$ \\
\hline$(*)$ & 0 & & 0 \\
\hline
\end{tabular}

\begin{tabular}{lrlr}
\hline \multicolumn{4}{c}{ Banking system of exporting country $\mathrm{C}\left(\mathrm{BS}_{\mathrm{C}}\right)$} \\
\hline Assets & \multicolumn{2}{c}{ Liabilities } \\
\hline$\left(1^{\prime \prime}\right)$ Deposit with ISI $(+z$ bancor $)$ & $+y \mathrm{MC}$ & Deposit of the payee & $+y \mathrm{MC}$ \\
$\left(2^{\prime \prime}\right)$ Deposit with ISI $(-z$ bancor) & $-y \mathrm{MC}$ & & \\
Securities (bought from country A) & $+y \mathrm{MC}$ & & $y \mathrm{MC}$ \\
$(*)$ Securities & $y \mathrm{MC}$ & Deposit of the payee &
\end{tabular}

Notes: $\mathrm{MA}=$ units of money A; $\mathrm{MC}=$ units of money $\mathrm{C} .(*)$ is the balance of those entries that are recorded in the relevant ledger.

therefore to deliver a purchasing power to country $\mathrm{C}$ instead of a pure promise of payment (as this occurs to date - see Rueff 1963, pp. 325-326). Similarly to the delivery-versuspayment protocol used in securities settlement systems, this delivery of a purchasing power (in the form of securities) from country A to country $\mathrm{C}$ will make sure that any country's trade deficit does not elicit a payment deficit (as occurs in the current 'non-system' for international payments). The entries (2), $\left(2^{\prime}\right)$ and $\left(2^{\prime \prime}\right)$ record the delivery of securities from country A to country $\mathrm{C}$, which finally pays for them in disposing of the settlement balances it was credited with as a result of entries (1), (1') and (1").

Once all relevant payments have been carried out, the end-of-period balance shows in Table 4 that no settlement balances remain with the international settlement institution let us call the supranational currency this institution issues in those payments that it carries out on behalf of its member countries the bancor. Entries (*) also show clearly that country C (a trade-surplus country) has no further claims on country A (a tradedeficit country), as the latter has delivered a purchasing power in the form of securities to the former country. All international payments are thereby final, in contrast to the current 'non-system' that, as a matter of fact, leaves the surplus country (C) with a claim on a bank deposit recorded with the deficit country (A) as shown in Table 2.

\section{CONCLUSION}

The analysis presented in this paper has pointed out that the global systemic crisis that has been ravaging a number of Western economies since the demise of Lehman 
Brothers in the United States on 15 September 2008 stems from monetary-structural flaws in the design of the national and international payment systems. Within countries, the endogenous nature of money and its close link with bank credit are not sufficiently reflected in the structure of the banks' book-keeping, which therefore needs to be refined, in order to separate in the banks' accounting the emission of money in income-generating payments from all credit lines that do not contribute to income production. Between countries, by contrast, the use of so-called 'key currencies' in payment for foreign trade (on goods, services and assets) gives rise to a monetarystructural disorder (revealed notably by increasing global imbalances), because it does not lead to payment finality in so far as trade-deficit countries record a payment deficit also. The international payment system therefore needs a monetary-structural reform, to set up an international settlement institution whose supranational currency will allow countries to make sure that any foreign-trade transaction is finally paid between them.

Provided that both domestic and international reforms are carried out in conformity with the essential distinction between money and credit, as explained in this paper, then it would be possible to avoid the failure of one or more financial institutions from threatening the stability of the whole financial and economic system. A systemic crisis cannot stem from a series of wrong decisions taken by any agents whatsoever, unless the payment system itself is structurally flawed. Rather than trying to regulate agents' forms of behaviour, national as well as multilateral supervisory authorities should concentrate on fixing the structural flaws of the payment architecture within and between countries. Intuitions of the reforms that are required in this respect have been provided by Ricardo and Keynes. It is now time to act in order to make sure that the structure of banking and finance respects the nature of money and credit, independently of agents' behaviour. This action is most urgent within euroland, as the euro-area crisis is threatening the whole process of European integration at the time of writing. As the analysis presented in this paper has shown, no financial capital (in the form of bank deposits) can ever leave the monetary space in which it has been formed as a result of the working of the local payment system. Once the monetary borders that define a national payment system disappear after the country joins a single currency area (such as euroland), this 'natural' protection against free cross-border capital movements disappears. This allows a financial capital formed in country A (say, in Italy) to move freely to country B (say, to Germany), both countries pertaining to the same monetary space as defined by the area-wide payment system. As shown by Sinn and Wollmershäuser (2011) and Tober (2011), among others, the so-called 'TARGET2' payment system within euroland has been recording increasing imbalances between creditor countries (in particular, Germany) and debtor countries (notably, Portugal, Ireland, Greece and Spain). These imbalances are among the empirical evidence about the 'non-viability' of a single currency (the euro) in a multinational monetary space that lacks a number of key features and institutions to make it a driver of economic growth and prosperity rather than a factor of imbalances and financial crisis, which no austerity measures will ever be able to resolve (see Rossi 2012 for analytical elaboration on this).

\section{ACKNOWLEDGMENTS}

This paper stems from a lecture that its author was invited to deliver at the University of Burgundy, Dijon, France, on 8 March 2012. The usual disclaimer applies. 


\section{REFERENCES}

Bossone, Biagio (2001), 'Circuit theory of banking and finance', Journal of Banking and Finance, 25(5): 857-890.

Cencini, Alvaro (1995), Monetary Theory, National and International, London and New York: Routledge.

Cencini, Alvaro (2001), Monetary Macroeconomics: A New Approach, London and New York: Routledge.

Cencini, Alvaro (2010), 'For a new system of international payments', Banks and Bank Systems, 5(1): 47-57.

Gnos, Claude (1998), 'The Keynesian identity of income and output', in Philippe Fontaine and Albert Jolink (eds), Historical Perspectives on Macroeconomics: Sixty Years After the General Theory, London and New York: Routledge, pp. 40-48.

Goodhart, Charles Albert Eric (1989), Money, Information and Uncertainty, 2nd edn, London and Basingstoke, UK: Macmillan (first published 1975).

Gourinchas, Pierre-Olivier and Hélène Rey (2007), 'From world banker to world venture capitalist: US external adjustment and the exorbitant privilege', in Richard H. Clarida (ed.), G7 Current Account Imbalances: Sustainability and Adjustment, Chicago and London: University of Chicago Press, pp. 11-55.

Graziani, Augusto (1990), 'The theory of the monetary circuit', Économies et Sociétés, 24(6): 7-36.

Graziani, Augusto (2003), The Monetary Theory of Production, Cambridge, UK: Cambridge University Press.

Greenspan, Alan (2004), 'The mortgage market and consumer debt', Remarks at America's Community Bankers Annual Convention, Washington, DC, 19 October 2004, available at http://www.federalreserve.gov/BoardDocs/Speeches/2004/20041019/default.htm.

Innes, Alfred Mitchell (1913), 'What is money?', Banking Law Journal, May: 377-408.

Keynes, John Maynard (1930 [1971]), A Treatise on Money, Volume 1: The Pure Theory of Money, London: Macmillan (reprinted in The Collected Writings of John Maynard Keynes, vol. V, London and Basingstoke, UK: Macmillan, 1971).

Keynes, John Maynard (1942 [1980]), 'Proposals for an International Clearing Union', in The Collected Writings of John Maynard Keynes, vol. XXV: Activities 1940-1944. Shaping the Post-War World: The Clearing Union, London and Basingstoke, UK: Macmillan, pp. 168-195.

Machlup, Fritz (1963), 'Reform of the international monetary system', in Herbert G. Grubel (ed.), World Monetary Reform: Plans and Issues, Stanford, CA and London: Stanford University Press and Oxford University Press, pp. 253-260.

Moore, Basil J. (2003), 'Saving is the accounting record of investment', in Philip Arestis, Michelle Baddeley and John McCombie (eds), Globalisation, Regionalism and Economic Activity, Cheltenham, UK and Northampton, MA: Edward Elgar, pp. 245-265.

Panzera, Fabio and Sergio Rossi (2011), “Too-big-to-fail” financial institutions: risks and remedies', International Journal of Trade and Global Markets, 4(3): 311-327.

Ricardo, David (1824 [1951]), Plan for the Establishment of a National Bank, in Piero Sraffa and Maurice Herbert Dobb (eds), The Works and Correspondence of David Ricardo, vol. IV: Pamphlets and Papers 1815-1823, Cambridge, UK: Cambridge University Press, pp. 276-300.

Rochon, Louis-Philippe and Sergio Rossi (2015), 'Horizontalism and structuralism: a suggested re-interpretation', in Louis-Philippe Rochon (ed.), Post-Keynesian Monetary Theory: Horizontalism and Structuralism Revisited - Reflections and Development, Cheltenham, UK and Northampton, MA: Edward Elgar, forthcoming.

Rossi, Sergio (2007), Money and Payments in Theory and Practice, London and New York: Routledge.

Rossi, Sergio (2009), 'International payment finality requires a supranational central-bank money: reforming the international monetary architecture in the spirit of Keynes', China-USA Business Review, 8(11): 1-20. 
Rossi, Sergio (2010), 'The 2007-9 financial crisis: an endogenous-money view', Studi e Note di Economia, 15(3): 413-430.

Rossi, Sergio (2011), 'Can it happen again? Structural policies to avert further systemic crises', International Journal of Political Economy, 40(2): 61-78.

Rossi, Sergio (2012), 'The monetary-structural origin of TARGET2 imbalances across Euroland', in Claude Gnos and Sergio Rossi (eds), Modern Monetary Macroeconomics: A New Paradigm for Economic Policy, Cheltenham, UK and Northampton, MA: Edward Elgar, pp. 221-238.

Rueff, Jacques (1963), 'Gold exchange standard a danger to the West', in Herbert G. Grubel (ed.), World Monetary Reform: Plans and Issues, Stanford, CA and London: Stanford University Press and Oxford University Press, pp. 320-328.

Rueff, Jacques and Fred Hirsch (1965), The Role and the Rule of Gold: An Argument, Princeton, NJ: Princeton University Press.

Schmitt, Bernard (1975), Théorie Unitaire de la Monnaie, Nationale et Internationale, Albeuve: Castella.

Schmitt, Bernard (1984), Inflation, Chômage et Malformations du Capital, Paris and Albeuve: Economica and Castella.

Schmitt, Bernard (1996), 'Unemployment: is there a principal cause?', in Alvaro Cencini and Mauro Baranzini (eds), Inflation and Unemployment: Contributions to a New Macroeconomic Approach, London and New York: Routledge, pp. 75-105.

Schumacher, Ernst Friedrich (1943), 'Multilateral clearing', Economica, 10(38): 150-165.

Sinn, Hans-Werner and Timo Wollmershäuser (2011), 'TARGET loans, current account balances and capital flows: the ECB's rescue facility', CESifo Working Paper, No 3500.

Stellian, Rémi (2010), 'Home equity extraction, growth, and the subprime crisis within the theory of the monetary circuit', European Journal of Economic and Social Systems, 23(1): 45-62.

Tober, Silke (2011), 'Die Europäische Zentralbank in der Kritik', IMK Report, No 27.

Williamson, John (1977), The Failure of World Monetary Reform, 1971-1974, New York: New York University Press. 